\title{
IMPLEMENTASI PERATURAN DAERAH NOMOR 12 TAHUN 2010 TENTANG RETRIBUSI PELYANAN PARKIR DI RUMAH SAKIT ARIFIN NU'MAN KECAMATAN PANCA RIJANG KABUPATEN SIDENRENG RAPPANG
}

\author{
Fatmawati \\ Fakultas IImu Sosial dan IImu Politik, Universitas Muhammadiyah Rappang \\ fatmawati43151099f1@gmail.com
}

\begin{abstract}
Abstrak
Penelitian ini bertujuan 1). Untuk mengetahui komunikasi, sumber daya, disposisi dan struktur birokrasi dalam mempengaruhi Implementasi Peraturan Daerah Nomor 12 Tahun 2010 tentang Retribusi Pelayanan Parkir di Rumah Sakit Arifin Nu'mang Kecamatan Panca Rijang Kabupaten Sidenreng Rappang 2). Untuk mengetahui bagaimana pelayanan parkir di Rumah Sakit Arifin Nu'mang Kecamatan Panca Rijang Kabupaten Sidenreng Rappang. Populasi dalam penelitian ini adalah 1600 pengguna jasa parkir. Teknik penarikan sampel yang digunakan adalah probability sampling lebih tepatnya menggunakan teknik Random sampling atau sampel acak. Adapun sampel yang digunakan sebanyak 94 responden dengan jenis penelitian deskriptif kuantitatif. Teknik pengumpulan data yang digunakan dalam penelitian ini adalah observasi, wawancara, kuesioner dan studi kepustakaan. Data yang terkumpul selanjutnya dianalisis menggunakan teknik analisis data dengan menggunakan tabel frekuensi dan skala likert. Berdasarkan hasil penelitian, faktor yang memengaruhi Implementasi Peraturan Daerah yaitu komunikasi dengan persentase 58\%, sumber daya dengan persentase $60 \%$, disposisi dengan persentase $56 \%$, dan struktur birokrasi dengan persentase $64 \%$, maka didapatkan rata-rata persentase yaitu $59 \%$ termasuk "kategori kurang baik". Adapun hasil penelitian dari variabel Pelayanan Parkir Di Rumah Sakit Arifin Nu'mang Kecamatan Panca Rijang Kabupaten Sidenreng Rappang, maka didapatkan rata-rata persentase $60.4 \%$ termasuk dalam kategori "kurang baik".
\end{abstract}

Kata Kunci: Implementasi, dan Pelayanan.

\section{Abstract}

This Research Tried 1). To find out communication, resources, disposition and bureaucratic structure in influencing the Implementation of Regional Regulation Number 12 of 2010 concerning Parking Service Retribution at Arifin Nu'mang Hospital, Panca Rijang District, Sidenreng Rappang District 2). To find out how parking services at Arifin Nu'mang Hospital, Panca Rijang District, Sidenreng Rappang Regency. The population in this study was 1600 parking service users. The sampling technique used is the probability of sampling which uses more random samples. The sample used was 94 respondents with quantitative descriptive research types. Data collection techniques used in this study were observation, interviews, questionnaires and literature studies. The collected data is then analyzed using data analysis techniques using frequency tables and likert scales. Based on the results of the study, the factors that influence the Implementation of Regional Regulations are communication with a percentage of $58 \%$, resources with a percentage of $60 \%$, disposition with $56 \%$, and bureaucratic structure with a percentage of $64 \%$, so that an average of $59 \%$ is included not good ". From the results of the study of Parking Service variables at Arifin Nu'mang Hospital, Panca Rijang District, Sidenreng Rappang District, the average percentage of $60.4 \%$ is included in the "less good" category.

Keywords: Implementation, and Services.

PRAJA| Volume 8| Nomor 2| Edisi Juni 2020 


\section{A. PENDAHULUAN}

Retribusi parkir adalah salah satu potensi yang harus dikelola untuk dijadikan sumber penerimaan daerah yang berasal dari dalam wilayah. Hal tersebut menjadi tolak ukur dalam menilai tingkat pendapatan asli daerah yang diperoleh wilayah tersebut. Hasil dari pendapatan tersebut akan dialokasikan untuk pembangunan wilayah itu sendiri, khususnya dalam membangun fasilitas dan sarana perbaikan lahan parkir yang berdampak pada tatakelola dalam pelaksanaan parkir berjalan dengan baik dan tidak mengganggu pengguna jalan lainnya. Penyelenggaraan fungsi pemerintahan daerah akan terlaksana secara optimal apabila adanya sumber penerimaan yang cukup pada daerah, dengan mengacu pada Undang - Undang tentang Perimbangan Keuangan antara Pemerintah Pusat dan Pemerintah Daerah, dimana besarnya disesuaikan dan diselaraskan dengan pembagian kewenangan antara pemerintah pusat dan daerah. Semua sumber keuangan yang melekat pada setiap urusan pemerintah yang diserahkan pada daerah menjadi sumber keuangan daerah.

Undang-Undang Nomor 25 Tahun 2009 tentang pelayanan publik, bahwa pelayanan publik adalah kegiatan atau rangkaian kegiatan dalam rangka pemenuhan kebutuhan pelayanan sesuai dengan peraturan perundang-undangan bagi setiap warga negara dan penduduk atas barang, jasa, dan atau pelayanan administratif yang disediakan oleh penyelengggara pelayanan publik. Dasar regulasi lainnya termasuk dalam Peraturan Pemerintah Nomor 65 Tahun 2005 tentang standar pelayanan minimal. Disini pelayanan publik terutama pemenuhan hak dasar masyarakat yang mencakup sosial, ekonomi dan pemerintahan menjadi agenda utama pemerintah, sehingga perlu diciptakan sebuah instrumen / standar yang bisa menjadi indikator pencapaian dan pemenuhan hak dasar tersebut oleh pemerintah.

Birokrasi publik berkewajiban dan bertanggung jawab untuk memberikan layanan yang baik dan profesional, karena dengan proses pelayanan yang lebih cepat dan berkualitas merupakan tuntunan bagi pemerintah sebagai penyedia layanan sekaligus pelayanan yang berkualitas adalah dambaan dan harapan seluruh masyarakat yang memenuhi kebutuhannya.

Ada lima indikator untuk mengukur kualitas pelayanan yang baik menurut Zeithaml dkk (Ratminto \& Atik Septi Winarsih 2016:175), yaitu: Tangibles atau ketampakan fisik, Realibity atau realibitas, Responsiveness atau responsivitas, Assurance atau kepastiana dan Empathy atau empati.

Walaupun pemerintah sudah membuat peraturan tentang parkir, sebagaimana Peraturan Daerah Nomor 12 Tahun 2010 tentang Retribusi Pelayanan Parkir namun, masih ada penyimpangan dan kekurang nyamanan mengenai tersedianya sarana dan prasarana. Fasilitas parkir menunjang keberhasilan dalam suatu pelayanan dan dapat mencapai kepuasan pelanggan. Kualitas pelayanan mempunyai peranan yang sangat penting dalam rangka memenuhi kepuasan konsumen. Kualitas pelayanan parkir yang baik akan membuat pengguna jasa parkir meningkat, dimana tempat yang paling aman mereka memarkir kendaraannya tanpa harus memikirkan kendaraannya aman atau tidak.

Seiring dengan meningkatnya aktivitas masyarakat, berdampak pada banyaknya pengguna kendaraan bermotor baik roda empat maupun roda dua. Hal tersebut secara otomatis akan meningkat pula terhadap penerimaan retribusi parkir jika dikelola dengan baik.

Pendapatan Asli Daerah berasal dari 4 (empat) sumber, yaitu : Pajak Daerah, Retribusi Daerah, Penerimaan dari pengelolaan aset daerah yang dipisahkan dan Penerimaan lainnya. Dari ke empat sumber tersebut, retribusi daerah menjadi sangat penting untuk menunjukkan kemampuan pemerintah dalam memberi layanan yang baik untuk meningkatkan aktivitas ekonomi masyarakat. Peranan retribusi daerah yang besar dalam pembentukan Pendapatan Asli Daerah mencerminkan kemampuan pemerintah untuk melayani semakin baik. Oleh karena itu, pelayanan parkir merupakan langkah bagi pemerintah untuk mencari solusi dalam meningkatkan penerimaan retribusi parkir, tentu dalam upayanya meningkatkan kontribusi retribusi parkir terhadap Pendapatan Asli Daerah (PAD). Salah satu sumber PAD adalah retribusi daerah dimana daerah tersebut memiliki kewenangan 
untuk melakukan pemungutan retribusi yang berkaitan dengan berbagai aspek kehidupan masyarakat. Hal ini dapat mengakibatkan peningkatan pendapatan daerah yang akan digunakan sebagai upaya pemenuhan kebutuhan daerah.

Peraturan Daerah Nomor 12 Tahun 2010 tentang Retribusi Pelayanan Parkir pada Pasal 10 tentang besarnya tarif retribusi dipungut berdasarkan jenis kendaraan Tarif retribusi setiap satu kali parkir ditetapkan sebagai berikut :

1. Kendaraan bermotor roda 2 (dua) Rp. 500

2. Kendaraan bermotor roda 3 (tiga) dan roda 4 (empat) Rp. 1.500

Berdasarkan pada peraturan daerah tersebut peneliti menemukan masalah mengenai tarif retribusi yang tidak sesuai dengan peraturan daerah nomor 12 tahun 2010 tentang retribusi pelayanan parkir pada pasal 10 tentang struktur dan besarnya tarif retribusi untuk roda dua (motor) Rp. 500, sedangkan implementasinya sebesar Rp. 3000, roda empat Rp. 1500, dan implementasinya Rp.5.000 sehingga menimbulkan kerugian bagi pengguna parkir dan pelayanan parkir masih belum maksimal, karena sikap juru parkir yang apatis kepada pengguna parkir. Hal ini membuat penulis tertarik untuk melakukan penelitian dengan judul "Implementasi Peraturan Daerah Nomor 12 Tahun 2010 Tentang Retribusi Pelayanan Parkir di Rumah Sakit Arifin Nu'mang Kecamatan Panca Rijang Kabupaten Sidenreng Rappang". Dengan tujuan untuk mengetahui komunikasi, sumber daya, disposisi dan struktur birokrasi dalam mempengaruhi Implementasi Peraturan Daerah Nomor 12 Tahun 2010 tentang Retribusi Pelayanan Parkir di Rumah Sakit Arifin Nu'mang Kecamatan Panca Rijang Kabupaten Sidenreng Rappang dan untuk mengetahui bagaimana pelayanan parkir di Rumah Sakit Arifin Nu'mang Kecamatan Panca Rijang Kabupaten Sidenreng Rappang.

Implementasi yaitu realisasi keputusan kebijakan yang mendasar, umumnya dalam bentuk Undang-Undang, namun dapat pula berbentuk permintaan, perintah atau putusan eksekutif yang urgen juga dapat pula putusan lembaga peradilan. Umumnya putusan tersebut mengidentifikasi problem yang hendak dipecahkan, serta dicantumkan secara jelas tujuan dan sasaran yang ingin dicapai dan berbagai metode untuk mengurutkan atau mengatur proses pelaksanaannya (Ahmad, Perilaku Birokrasi dan Pengambilan Keputusan , 2011).

Ripley dan Frenklin (Winarto, 2016) berpendapat bahwa implementasi adalah apa yang terjadi setelah Undang-Undang diterapkan yang memberikan otoritas program, kebijakan, keuntungan (benefit), atas suatu jenis keluaran yang nyata (tangible output). Sementara itu, Grindle juga memberikan pandangannya tentang implementasi dengan mengatakan bahwa secara umum, tugas implementasi adalah menbentuk suatu kaitan (linkage) yang memudahkan tujuan-tujuan kebijakan bisa direalisasikan sebagai dampak dari suatu kegiatan pemerintah. Oleh karena itu, tugas implementasi mencakup terbentuknya "a policy delivery sistem," dimana sarana-sarana tertentu dirancang dan dijalankan dengan harapan sampai tujuan-tujuan yang diinginkan. Selanjutnya, Van Meter dan Van Horn membatasi implementasi kebijakan sebagai tindakan-tindakan yang dilakukan individuindividu (atau kelompok-kelompok) pemerintah maupun swasta yang diarahkan untuk mencapai tujuan-tujuan yang telah ditetapkan dalam keputusan-keputusan kebijakan sebelumnya. Tindakan-tindakan ini mencakup usaha-usaha untuk mengubah keputusan-keputusan menjadi tindakan-tindakan operasional dalam kurung waktu tertentu maupun dalam rangka melanjutkan usaha-usaha untuk mencapai perubahan-perubahan besar dan kecil yang ditetapkan oleh keputusan-keputusan kebijakan.

Menurut Edward III (Subarsono, 2006) mengemukakan dua presmis untuk keperluan studi implementasi kebijakan yaitu prakondisiprakondisi apakah yang diperlukan untuk keberhasilan implementasi kebijakan serta hambatan-hambatan apa yang di hadapi dalam penerapannya. Untuk menjawab pertanyaan tersebut kemudian didefenisikan 4 faktor dalam menginplementasikan kebijakan publik yaitu:

1. Faktor Komunikasi Implementasi kebijakan dapat berjalan secara efektif, makayang bertanggung jawab terhadap implementasi sebuah kebijakan harus mengetahui apa yang harus dilakukakannya. 
Faktor komunikasi ini menunjukkan peranan sebagai acuan agar pelaksana kebijakan mengetahui persis apa yang akan mereka kerjakan. Ini berarti komunikasi juga dapat dinyatakan dengan perintah dari atasan terhadap pelaksana-pelaksana kebijakan sehingga penerapan kebijakan tidak keluar dari sasaran yang dikehendakinya. Dengan demikian komunikasi tersebut harus dinyatakan dengan jelas, tepat, dan konsisten.

\section{Faktor Sumber Daya}

Sumber daya penting meliputi staf dalam ukuran yang tepat dengan keahlian yang diperluakan, informasi yang cukup dan relevan tentang cara untuk mengimplementasikan kebijakan dan dalam penyesuain lainnya yang terlibat di dalam implementasi. Faktor sumber daya mempunyai peranan pentin dalam implementasi kebijakan, karen bagaimanapun jelas dan konsistennya ketentuan-ketentuan atau aturan-aturan suatu kebijakan, jika para personil yang bertanggung jawab mengimplementasikan kurang mempunyai sumber-sumber untuk melakukan pekerjaan secara efektif, maka implementasi kebijakan tersebut tidak akan bisa efektif.

3. Faktor disposisi / sikap pelaksana

Faktor ketiga sebagai pertimbangan dalam mengimplementasikan menurut Edward III (1980:11) menegaskan sikap pelaksana merupakan faktor penting ketiga dalam implementasi kebijakan publik. Jika implementasi kebijakan diharapkan berlangsung efektif, para pelaksana kebijakan tidak hanya harus menegtahui apa yang harus dilakukan dan memiliki kapabilitas untuk melaksanakannya tetapi mereka juga harus mempunyai keinginan melaksanakan kebijakan tersebut. Kebanyakan para pelaksana menggunakan sedapat mungkin otoritas dalam mengimplementasikan sebuah kebijakan. Salah satu alasan mengenai hal ini disebabkan oleh independensi mereka terhadap pembuat kebijakan.

4. Faktor Struktur Birokrasi

Meskipun sumber daya untuk mengimplementasikan kebijakan telah mencukupi dan para pelaksana mengetahui apa yang harus dilakukan serta bersedia melaksanakannya, implementasi masih terhambat olehinefisiensi struktur birokrasi.
Para pelaksana kegiatan akan mengetahui apa yang harus dilakukan dan mempunyai keinginan, sumber daya untuk melakukan kebijakan, tetapi mereka akan tetap dihambat proses implementasinya oleh struktur organisasi yang mereka layani. Asal-usul karakteristik organisasi, fragmentasi kebijakan. Mereka selalu menghambat implementasi kebijakan, pemborosan sumber daya, menyebabakan tindakan yang diharapkan, menghambat koordinasi, akibat proses kebijakan pada maksud yang berlawanan, dan sebab beberapa kebijakan yang gagal.

Menurut Moenir (Sinambela, 2010). Istilah pelayanan berasal dari kata "layan" yang artinya menolong menyediakan segala apa yang diperlukan oleh orang lain, untuk perbuatan melayani. Pada dasarnya setiap manusia membutuhkan pelayanan, bahkan secara ekstrim dapat dikatakan bahwa pelayanan tidak dapat dipisahkan dengan kehidupan manusia Pelayanan adalah proses pemenuhan kebutuhan melalui aktivitas orang lain yang langsung. Pelayanan pada dasarnya dapat didefinisikan sebagai aktivitas seseorang, kelompok dan organisasi baik langsung maupun tidak langsung untuk memenuhi kebutuhan. Pelayanan berarti melayani suatu jasa yang dibutuhkan oleh masyarakat dalam segala bidang. Kegiatan pelayanan kepada masyarakat merupakan salah satu tugas dan fungsi admnistrasi negara.

Menurut Sinambela (Pasolong, 2013) Pelayanan publik adalah sebagai setiap kegiatan yang dilakukan oleh pemenrintah terhadap sejumlah manusia yang memiliki setiap kegiatan yang menguntungkan dalam suatu kumpulan atau kesatuan, dan menawarkan kepuasan meskipun hasilnya tidak terikat pada suatu produk secara fisik.

Agung Kurniawan (Pasolong, 2013:128) mengatakan bahwa pelayanan publik adalah pemberian pelayanan (melayani) keperluan orang lain atau masyrakat yang mempunyai kepentingan pada organisasi itu sesuai dengan aturan pokok dan tata cara yang telah ditetapkan.

\section{B. METODE PENELITIAN}

Lokasi pada penelitian ini yaitu di Rumah Sakit Arifin Nu'mang Kecamatan Panca Rijang 
Kabupaten Sidenreng Rappang. Waktu penelitian ini selama dua bulan yaitu pada awal bulan Maret sampai awal bulan Mei Tahun 2019 setelah diterbitkannya surat izin untuk penelitian. Penelitian ini menggunakan tipe penelitian deskriptif kuantitatif, dengan metode inii diharapkan dapat memberikan gambaran secara cermat, jelas, dan objektif mengenai masalah yang sedang diteliti. Sedangkan jenis penelitian yang dilakukan adalah survei dimana kegiatan penelitian menggunakan kuesioner dan wawancara sebagai instrumen dalam pengumpulan data di lapangan. Dalam penelitian terdapat satu variabel yakni implementasi.

Menurut Margono 2014 (Ahmad, Metode Penelitian Administrasi Publik, 2015), populasi adalah seluruh data yang menjadi perhatian kita dalam suatu ruang lingkup dan waktu yang kita tentukan. Jadi populasi berhubungan dengan data, bukan manusianya. Kalau setiap manusia memberikan suatu data, maka banyaknya atau ukuran populasi akan sama dengan banyaknya manusia. Dengan demikian yang menjadi populasi dalam penelitian ini adalah masyarakat yang menggunakan jasa parkir di Rumah sakit Arifin Nu'mang Kecamatan Panca Rijang Kabupaten Sidenreng Rappang sebanyak 1.600 selama satu bulan.

Teknik penarikan sampel adalah Probability Sampling. Probability Sampling adalah teknik pengambilan sampel yang memberikan peluang atau kesempatan yang sama bagi setiap unsur atau anggota populasi untuk dipilih menjadi sampel. Teknik Probability Sampling yang digunakan dalam pengambilan sampel pada penelitian ini lebih tepatnya peneliti menggunakan teknik Random Sampling atau sampel acak dari populasi keseluruhan masyarakat yang berkunjung / pasien di Rumah Sakit Arifin Nu'mang Kecamatan Panca Rijang Kabupaten Sidenreng Rappang. Teknik pengambilan sampel menggunakan rumus Slovin dalam Ahmad (2015: 148) sebagai berikut:

$$
\mathrm{n}=\frac{N}{1+N(e)^{2}}
$$

Keterangan:

$\mathrm{n}$ : Ukuran Sampel

$\mathrm{N}$ : Ukuran Populasi e : Persen kelonggaran ketidak telitian karena kesalahan

Pengambilan sampel yang masih dapat ditolerir atau diinginkan pengambilan sampel ini dilakukan pada tingkat kepercayaan $90 \%$ atau nilai kritis $10 \%$ sehingga ukuran sampel dapat dihitung sebagai berikut:

$$
\begin{aligned}
n & =\frac{1.600}{1+1.600(10 \%)^{2}} \\
& =\frac{1.600}{1+1.600(0,1)^{2}} \\
& =\frac{1.600}{1+1.600(0,01)} \\
& =\frac{1.600}{1+17} \\
& =\frac{1.600}{17} \\
& =94,11
\end{aligned}
$$

Dari perhitungan diatas, maka sampel yang didapat dalam penelitian ini adalah 94 sampel yaitu pengguna jasa parkir di Rumah Sakit Arifin Nu'mang Rappang.

Yaitu mengadakan pengamatan secara langsung di mana observasi dapat dilakukan dengan tes, kuesioner, ragam gambar dan rekaman. Pedoman observasi berisi sebuah daftar jenis kegiatan yang mungkin timbul dan akan diamati, dalam Ahmad (2015: 170).

Data yang diperoleh melalui kuesioner dianalisis dengan melalui skala Likert. Menurut Sugiyono (dalam Ahmad 2015:155) skala Likert digunakan untuk mengukur sikap, pendapat, persepsi seseorang atau kelompok orang tentang fenomena sosial yang ditetapkan secara spesifik oleh peneliti sebagai variabel penelitian. Dengan model skala likert, maka variabel yang akan diukur dijabarkan menjadi indikator variabel. Kemudian indikator tersebut dijadikan sebagai titik tolak untuk menyusun item-item instrument yang dapat berupa pertanyaanpertanyaan.

Beberapa jawaban dari pertanyaan yang sesuai dengan tujuan penelitian diberi bobot nilai, dengan nilai tertinggi lima dan nilai terendah satu. Rata-rata skor dari hasil pertanyaan akan dikelompokkan menjadi lima kategori.

Berdasarkan keterangan di atas maka peneliti menggunakan radiasi yaitu Sangat baik, Baik, Cukup baik, Kurang baik, Tidak baik untuk 
memudahkan menganalisis variabel-variabel. Selanjutnya dibuat berdasarkan interval nilai presentase sebagai berikut:

Penentuan kriteria rata-rata persentase perlu adanya skala interval dalam menentukan ratarata persentase. Menurut Nasir (2005: 448) rumus untuk mencari interval sebagai berikut:

$$
\begin{aligned}
& \text { interval }(i)=\frac{100}{\text { Maka: }} \\
& \text { jumlah kategori (likert) }
\end{aligned}
$$

$$
\text { Interval }(i)=\frac{100}{5}=20
$$

Jadi interval (i) adalah 20, jarak dari terendah $0 \%$ hingga tertinggi 100\%. Dengan demikian dapat diketahui kriteria rata-rata persentase berdasarkan interval.

\section{HASIL DAN PEMBAHASAN}

1. Faktor-faktor yang mempengaruhi Implementasi.

Faktor yang mempengaruhi Implementasi memiliki empat indikator yang telah diukur melalui tabel frekuensi diantaranya, Rata-rata persentase yaitu $58 \%$ maka dapat ditarik kesimpulan bahwa, penyampaian infomasi dari petugas parkir tentang tarif retribusi kepada pengguna parkir masuk dalam kategori kurang terlaksana dengan baik. Rata-rata persentase yaitu $60 \%$ maka dapat ditarik kesimpulan bahwa, atribut yang digunakan petugas parkir di Rumah Sakit Arifin Nu'mang masuk dalam kategori kurang baik. Rata-rata persentase yaitu $56 \%$ maka dapat ditarik kesimpulan bahwa, sikap pemerintah dalam menginformasikan paraturan retribusi relayanan parkir di Rumah Sakit Arifin Nu'mang masuk dalam kategori kurang terlaksana dengan baik. Rata-rata persentase yaitu $64 \%$ maka dapat ditarik kesimpulan bahwa, pembagian tugas para petugas parkir di Rumah Sakit Arifin Nu'mang masuk dalam kategori terlaksana baik. Hasil rata-rata persentase dari 4 item pertanyaan pada Faktor-faktor yang mempengaruhi Implementasi di atas, maka didapatkan rata-rata hasil persentase yaitu 59,5\% jadi dapat ditarik suatu kesimpulan bahwa faktor - faktor yang mempengaruhi implementasi berada pada kategori kurang terlaksana dengan baik.
2. Pelayanan
Rekapitulasi
tanggapan
responden mengenai variabel Pelayanan.

Hasil dari rekapitulasi pelayanan diantaranya, Rata-rata persentase yaitu $56 \%$ maka dapat ditarik kesimpulan bahwa, ketersediaan fasilitas parkir di Rumah Sakit Arifin Nu'mang masuk dalam kategori kurang baik. Rata-rata persentase yaitu $66 \%$ maka dapat ditarik kesimpulan bahwa, kejujuran petugas parkir yang melakukan pelayanan masuk dalam kategori baik. Rata-rata persentase yaitu $58 \%$ maka dapat ditarik kesimpulan bahwa, daya tanggap / respon para petugas parkir dalam memberikan pelayanan parkir di Rumah Sakit Arifin Nu'mang masuk dalam kategori kurang baik. Rata-rata persentase yaitu $62 \%$ maka dapat ditarik kesimpulan bahwa, rasa tanggung jawab para petugas parkir dalam menjaga dan mengatur kendaraan di Rumah Sakit Arifin Nu'mang masuk dalam kategori baik. Rata-rata persentase yaitu $60 \%$ maka dapat ditarik kesimpulan bahwa, sikap ramah yang ditunjukkan oleh petugas parkir dalam memberikan pelayanan kepada masyarakat masuk dalam kategori kurang baik. Hasil ratarata persentase dari 5 item pertanyaan pada variabel Pelayanan di atas, maka didapatkan rata-rata hasil persentase yaitu $60,4 \%$ jadi dapat ditarik suatu kesimpulan bahwa indikator Pelayanan berada pada kategori kurang baik.

\section{Kesimpulan}

Pada bab terdahulu telah diuraikan mengenai hasil penelitian dan pembahasan maka penulis menarik simpulan sebagai berikut:

1. Berdasarkan hasil penelitian, faktor yang memengaruhi Implementasi Peraturan Daerah yaitu komunikasi dengan persentase $58 \%$, sumber daya dengan persentase $60 \%$, disposisi dengan persentase $56 \%$, dan struktur birokrasi dengan persentase 64\%, maka didapatkan rata-rata persentase yaitu $59 \%$ termasuk kategori "kurang baik".

2. Adapun hasil penelitian dari variabel Pelayanan Parkir Di Rumah Sakit Arifin Nu'mang Kecamatan Panca Rijang Kabupaten Sidenrerng Rappang, maka didapatkan rata-rata persentase $60.4 \%$ termasuk dalam kategori "kurang baik". 


\section{E. REFERENSI}

Ahmad, J. (2011). Perilaku Birokrasi dan Pengambilan Keputusan . Makassar: UNM.

Ahmad, J. (2015). Metode Penelitian Administrasi Publik. Yogyakarta: Gava Media.

Pasolong, H. (2013). Kepemimpinan Birokrasi. Bandung: CV. Alfabeta.

Sinambela, L. P. (2010). Reformasi Pelayanan Publik. Jakarta: PT. Bumi Aksara.

Subarsono. (2006). Analisa Kebijakan Publik Konsep, Teori dan Aplikasi. Yogyakarta: Pustaka Belajar.

Sugiyono. (2014). Metode Penelitian Pendidikan Pendekatan Kuantitatif dan Kualitatif. Bandung: Alfabeta.

Winarto, B. (2016). Kebijakan Publik Era Globalisasi Teori, Proses dan Studi Kasus Komparatif. Yogyakarta: CAPS (Center of Academic Publishing Service.

Saifullah Dkk. Implementasi Kebijakan Peraturan Daerah Nomor 18 Tahun 2016 Tentang Kawasan Tanpa Rokok Di Rumah Sakit Arifin Nu'mang Kabupaten Sidenreng Rappang. J Moderat. 2019;5:44-55. 